\title{
Stage I Esophageal Squamous Cell Carcinoma AJCC v7
}

National Cancer Institute

\section{Source}

National Cancer Institute. Stage I Esophageal Squamous Cell Carcinoma A/CC v7. NCI

Thesaurus. Code C5022.

Stage I includes: IA (T1, N0, M0, G1, GX, Tumor location: Any); IB (T1, N0, M0, G2-3, Tumor location: Any); (T2-3, N0, M0, G1, GX, Tumor location: Lower, X). T1: Tumor invades lamina propria, muscularis mucosae, or submucosa. T2: Tumor invades muscularis propria. T3: Tumor invades adventitia. N0: No regional lymph node metastasis. M0: No distant metastasis. G1: Well differentiated. GX: Grade cannot be assessed-stage grouping as G1. G2: Moderately differentiated. G3: Poorly differentiated. Tumor location: Location of the primary cancer site is defined by the position of the upper (proximal) edge of the tumor in the esophagus. (AJCC 7th ed.) 